but less striking, growth of natural vegetation has occurred on the Rousdon and Charton Cliffs. Owing to the inaccessibility of much of the ground and the continued risk of further slips, theie has been an almost unique freedom from human disturbance there. Permits to collect specimens or to visit parts of the reserve away from the footpath will be needed, application for which should be made to the Conservancy's regional officer for the south-west at the Furzebrook Research Station, Wareham, Dorset; the warden for the reserve is Mr. L. A. Pritchard, Lynch Cottage, Rousdon, near Lyme Regis.

\section{THE MUSEUMS ASSOCIATION ANNUAL CONFERENCE IN THE NETHERLANDS}

\begin{abstract}
$7 \mathrm{HE}$ sixty-second annual conference of the Museums Association was held jointly with De Museumdag in Amsterdam during June 27-30. Owing to the provisions of the Companies' Act, it was necessary to hold the annual general meeting in Britain, and this took place at University College, London, before delegates embarked for Holland. After welcoming some 320 delegates to the conference, the resiring president, Dr. F. S. Wallis (director of the City Museum, Bristol), gave an address on some of the recent activities of the Association. $H_{e}$ outlined the negotiations with the Government concerning assistance to museums and more especially to private and trustee museums. The generous help of the United Kingdom Carnegie Trustees was acknowledged, and the great effect of their grants on museum work in Britain over the past twenty-six years was stressed. Dr. Wallis also referred to the value of the various regional federations, the courage of the governing bodies and curators of small museums, and the need for more committees to utilize the provisions of the Local Government Act of 1948 whereby financial assistance may be given to further local efforts of a cultural character.
\end{abstract}

In Amsterdam, delegates were joined by member's of De Museumdag under their president, Dr. J. C. Ebbinge Wubben, and an official welcome was given by $\mathrm{Mr}$. F. P. Th. Rohling on behalf of the Minister of Education, Arts and Sciences and the Burgomaster of Amsterdam. Afterwards, Prof. E. K. Waterhouse read a paper on "British Collections and Dutch Art", in which he reviewed the interrelationships of English and Dutch art with especial reference to the seventeenth-century artists. Another series of papers, by Dr. A. B. de Vries, Sir Philip Hendy, Dr. W. E. Swinton and Dr. D. B. Harden, discussed museum displays in the Netherlands and Britain since 1945. The conference was unusual in that papers were reduced to those already mentioned, and visits to museums and art galleries to study technical and display methods were increased to the maximum possible. During the period the institutions in Amsterdam, Rotterdam, The Hague, the National Park in Otterlo, Arnhem, Leyden, Gouda, Utrecht and Delft were visited. Hospitality was lavish on all occasions.

The president of the Museums Association for 1956-57 is Sir Philip Hendy (director of the National Gallery, London), and the next annual conference of the Association will be held in Bristol during July $8-12,1957$.

\section{METEOROLOGICAL PROGRAMME OF THE INTERNATIONAL GEOPHYSICAL YEAR}

A NUMBER of important articles on the meteorA ological programme for the International Geophysical Year, planned by the responsible Working Group of the World Meteorological Organization, with Prof. J. van Mieghem (Belgium) as chairman, are to be found in the January and April numbers of the Organization's Bulletin. The intention of the programme is to increase knowledge of the meteorology of the tropics and of the upper air in all latitudes. Priority has been given to problems which are fundamentally world-wide in character, so that their solution calls for effective international collaboration, and local or regional questions have not been considered.

In synoptic and dynamical meteorology the problems to be attacked are as follows: the redistribution on a planetary scale of momentum, absolute vorticity, energy and momentum, including frictional and topographical effects; exchange of heat and momentum between the atmosphere and oceans; flow patterns in low latitudes, including interaction between the southern and northern hemispheres; and the distribution of precipitation, especially over the oceans, in relation to large-scale flow patterns. The data collected in this work will assist also in such problems as meteorological influences on the Earth's rotation and the 'model' atmospheres used in numerical forecasting. In physical meteorology the subjects for observation are the distributions of ozone and water vapour, the heat balance of the atmosphere, and the largescale features of the electric field in the atmosphere.

To ensure comparability of records, it is recommended that the instruments to be used should be compared with national standards and that the World Meteorological Organization should arrange a world-wide comparison of national radiosondes. It is recommended that special efforts be made by every country to make daily two radiosonde observations of pressure, temperature and humidity, and four of wind, up to at least $50 \mathrm{mb}$. (about $78,000 \mathrm{ft}$.) and., if possible, to attain the $10-\mathrm{mb}$. level $(103,000 \mathrm{ft}$.$) . As regards radiation, the Working$ Group recommends that observations of the total short-wave radiation (that is, direct solar beam and short-wave sky radiation) should be made at stations in all types of elimate to establish for all parts of the world the empirical formulæ for determining global radiation from sunshine duration. Besides this, measurements are recommended of the ultraviolet radiation, of the spectral distribution of energy in solar radiation, and of the long-wave radiation at the surface. The vertical distribution of ozone, so important in studies of ultra-violet radiation, is to be measured, in particular in the sub-tropical anticyclone belt.

For the study of meridional exchanges it is important to be able to draw good meridional cross. sections. The Group proposes that meridional sections shall be drawn from pole to pole along meridians $180^{\circ}, 140^{\circ}$ E., $75^{\circ}$ E., $10^{\circ}$ E. and $75^{\circ}$ W. The first is especially important as giving an oceanic section almost from pole to pole. Minor sections are to be made along other meridians - for example, along the tropical parts of $30^{\circ} \mathrm{E}$. and $110^{\circ} \mathrm{E}$. It is 
hoped that aerological stations will be set up in sufficient numbers along these meridians to enable good cross-sections to be drawn.

As regards publication of meteorological data for the year, the World Meteorological Organization has taken the bold step of deciding to use microcards. National meteorological services are to be asked to send a copy of the observational records of their stations to the secretariat, where they will be printed on microcards and sold. A trial of the method is to be held in January 1957.

\section{THE PHYSICAL SOCIETY ANNUAL REPORT FOR 1955}

A $T$ the annual general meeting of the Physical Society, held in London at the offices of the Society on May 24, the reports of the council and of the honorary treasurer and the accounts and balance sheet for 1955 were presented and adopted, and the officers and council for 1956-57 were elected. The council reported that the balance of income over expenditure for the year under review was $£ 1,220$. However, it should be noted that expenditure for 1955 was more than $£ 9,000$ greater than for 1954 , $£ 4,000$ of this increase being due to the greater expense of housing the thirty-ninth annual exhibition of scientific instruments and apparatus in the New Hall of the Horticultural Society instead of in the Imperial College of Science and Technology, London, where former exhibitions were held. Interest in the exhibition was as great as ever, the attendance exceeding eighteen thousand, and the increased expenditure on the exhibition was more than balanced by a gain in receipts from exhibitors.

The activities of the Society during the year included five science meetings in London; three joint colloquia with the Institute of Physics on electron physics in London; a three-day meeting at the Atomic Energy Research Establishment, Harwell, during March 31-April 2; and two-day meetings at the Universities of Liverpool and Cambridge during July 5-6 and December 13-14, respectively. A highly successful innovation was a Fellow's luncheon, which was held in London on April 25, the opening day of the annual exhibition. The eighteenth Thomas Young Oration was delivered by Dr. W. S. Stiles, who spoke on the basic data of colour matching and some related aspects of visual theory, and the thirty-ninth Guthrie Lecture by Prof. E. C. Stoner on magnetism in retrospect and prospect ${ }_{t}$; both these lectures have been published in the "Year Book of the Physical Society, 1955". Dr. N. Kurti was the recipient of the tenth Holweck Medal of the Société Française de Physique and the Holweck Prize of the Physical Society; the presentation took place in Paris on May 26, when Dr. Kurti delivered the Holweck Discourse entitled "Le domaine des températures où regnent les spins" (J. Phys. et le Rad., 17, 85; Feb. 1956). The thirty-second Duddell Medal was presented to Dr. R. Kompfner, who gave an address on travelling-wave tubes, and the eleventh Charles Vernon Boys Prize to Dr. J. W. Mitchell, who spoke on some of his work on photographic emulsions.

The Society continues to be represented on various committees and institutions, details of which are listed in the annual report, together with brief accounts of the activities of the four Groups of the Society-the
Colour, Optical, Low Temperature and Acoustics Groups. The summer meetings of the Colour and Optical Groups were held at the Paint Research Station, Teddington, and University College, London, respectively, while the Low Temperature Group for its summer meeting paid a visit to the British Oxygen Company's air separation plant at Brinsworth, to the United Coke and Chemicals Company's hydrocarbon separation plant at Handsworth and to the Low Temperature Physics Laboratory at the University of Leeds.

In the section of the report dealing with publications, it is stated that, after a three years trial, the reprints scheme, whereby members and subscribers of the Society were able to purchase reprints of the papers published in the Society's Proceedings, has had to be discontinued. The general demand for the scheme was far too small to justify the large expense involved. Two conference reports, "Defects in Crystalline Solids", the report of a conference held in Bristol during 1954, and "The Physics of the Ionosphere", the report of a conference held in Cambridge during 1954, which were mentioned in the 1954 annual report, were published during 1955, and Volume 18 of "Reports on Progress in Physics", containing ten specialist articles, was issued in September. The flow of papers to the Proceedings increased during 1955. 265 papers and 115 research notes and letters to the editor were accepted for publication, as compared with 215 and 111 respectively in the previous year. Seventy-three manuscripts were either rejected or withdrawn. A new annual publication, commenced in the autumn of 1955, was "The Year Book of the Physical Society", containing the texts of the presidential address, the Guthrie Lecture and other special lectures to the Society, in addition to the annual report and accounts.

The officers and council of the Society for 1956-57 are as follows: President, Prof. N. F. Mott; Vice. Presidents (in addition to those who have filled the office of president), Dr. A. B. Wood, Prof. S. Devons, Prof. F. Llewellyn Jones and Prof. H. Jones; Honorary Secretaries, Dr. C. G. Wynne and Dr. H. H. Hop. kins ; Honorary Foreign Secretary, Prof. E. N. da C. Andrade; Honorary Treasurer, Mr. A. J. Philpot; Honorary Librarian, Dr. R. W. B. Pearse; New Ordinary Members of Council, Dr. V. E. Cosslett, Dr. D. Gabor and Mr. E. S. Shire.

\section{THE DELI PALM}

A RECENT issue of the Journal of the West African Institute for Oil Palm Research (No. 3, pp. $5-87 ; 1955)$ contains a number of articles of interest both to botanists and planters. It is an odd and sometimes disconcerting fact that a haze of obscurity overhangs the origin of so many of our major crops. This is particularly true of the Deli palm - a strain of Elaeis guineensis that has been cultivated with great success in the East concerning which an important article is contributed by A. F. M. Broekmans and F. W. Toovey. Seed of the Deli palm was introduced into Nigeria at various times before the Second World War in the hope that it would afford a means both of increasing the yield of palm oil and of resisting some of the diseases to which the local West African oil palm is subject. It is reported that, over the first eight-year period, the local strains gave a much higher yield of fruit bunches than the Deli strains; 